\title{
Peranan Kepemimpinan dalam Meningkatkan Etos Kinerja Pegawai pada Biro Tata Pemerintahan Sekretariat Daerah Provinsi Aceh
}

\author{
Dedi Sufriadi ${ }^{1}$ \\ Akademi Sekretari dan Manajemen Nusantara \\ sangpresiden01@gmail.com
}

\begin{abstract}
Abstrak
Penelitian ini tentang peranan kepemimpinan dalam meningkatkan etos kinerja pegawai pada Biro Tata Pemerintahan Sekretariat Daerah Provinsi Aceh. Pengumpulan data menggunakan dua metode yaitu studi kepustakaan (library research) dan studi lapangan (field research). Melalui studi lapangan Peneliti melaksanakan melalui dua teknik yaitu : pengamatan (observasi), yaitu cara pengumpulan data yang dilakukan dengan melihat dan terjun langsung pada rutinitas yang terjadi pada Biro Tata Pemerintahan Sekretariat Daerah Provinsi Aceh dan melalui wawancara (interview), yaitu dengan mengadakan wawancara dengan staff-staff pada Biro Tata Pemerintahan Sekretariat Daerah Provinsi Aceh. Hasil penelitian didapati Biro Tata Pemerintahan pada Sekretariat Daerah Provinsi Aceh mempekerjakan 62 orang pegawai yang berada kepemimpinan kepala Biro. Namun jumlah komposisi pegawai yang lebih besar dari beban kerja membuat kinerja pegawai pada Biro ini perlu diperhatikan. Masih terdapat sejumlah pegawai yang tidak mendapatkan pekerjaan dengan jelas sehingga membuka peluang bagi mereka untuk menggunakan waktu dengan kegiatan-kegiatan yang tidak bermanfaat. Kemudian kebijakan penempatan dan pembagian kerja yang tidak dilakukan secara propesional juga membuat kinerja pegawai pada Biro ini masih perlu diperhatikan. Di tengah semakin cepatnya perubahan lingkungan kerja yang ikut mempengaruhi perilaku kerja pegawai, maka Pemerintahan pada Sekretariat Daerah Provinsi Aceh membutuhkan pimpinan yang berkualitas agar masalah-masalah yang ada kaitan dengan etos kerja dan kinerja pegawai dapat terselesaikan
\end{abstract}

Kata kunci: Peranan Kepemimpinan, Etos Kinerja, Pegawai

\section{Pendahuluan}

Hadirnya Undang-Undang Republik Indonesia No 5 Tahun 2014 Tentang Aparatur Sipil Negara yang menyebutkan bahwa: "Aparatur Sipil Negara selanjutnya adalah disebut sebagai Pegawai Negeri Sipil dan Pegawai Pemerintah dengan perjanjian kerja yang diangkat oleh pejabat pembina kepegawaian \& diberikan tugas dalam suatu jabatan pemerintahan atau diberikan tugas negara lain dan digaji berdasarkan peraturan perundang-undangan". Walaupun reformasi birokrasi telah dilaksanakan lebih dari satu darsawarsa, namun kinerja Pegawai Negeri Sipil masih belum memperlihatkan perubahan dari waktu ke waktu.

Berdasarkan Peraturan Gubernur Nomor 15 Tahun 2008 Biro Tata Pemerintahan "mempunyai tugas menyiapkan bahan pembinaan, evaluasi penyelenggaraan pemerintahan umum, pengembangan perangkat daerah serta pembinaan otonomi daerah dan pembinaan perangkat pemerintah mukim dan gampong, serta kependudukan dan urusan pemerintahan yang bersifat tampung tentra". Biro Tata Pemerintahan merupakan salah satu dari 9 (sembilan) Biro pada Kantor Sekretariat Daerah Provinsi Aceh yang bertugas membantu Gubernur melalui Asisten Pemerintahan yang bertanggung jawab kepada Sekretaris Daerah.

Kinerja pegawai pada Biro Tata Pemerintahan pada Sekretariat Daerah Aceh tidak terlepas dari peran kepemimpinan. Dengan peran kepemimpinan yang efektif, pimpinan dapat melakukan

${ }^{1}$ Korespondensi: Dedi Sufriadi. Akademi Sekretari dan Manajemen Nusantara. Jalan T. Nyak Arief No. 333 Jeulingke Banda Aceh Aceh, Indonesia. Sangpresiden01@ gmail.com 
koordinasi atas seluruh aktivitas pelayanan publik tanpa adanya konflik dan permasalahan yang menghambat, dapat memberi pengarahan atas pekerjaan konseptual bawahan secara lebih manusiawi dan dengan cara-cara yang santun. Dengan peran kepemimpinan yang efektif, pimpinan juga ikut memberi umpan balik berupa pengakuan dan penghargaan yang setimpal atas prestasi bawahan. Sehingga kondisi ini akan memunculkan dorongan yang kuat dalam diri pegawai dan akhirnya meningkatkan kinerja mereka.

Lengkapnya kegiatan pemerintahan daerah telah membawa pengaruh yang signifikan terhadap perilaku etos kerja pegawai pada Biro Tata Pemerintahan. Kondisi ini membuat banyak dari pegawai terbebani dengan tugas-tugas baru yang arah dan prosedurnya tidak selamanya jelas. Sehingga diperlukan peran kepemimpinan yang efektif dan tepat untuk mengarahkan bawahan dalam suatu bentuk hubungan vertikal. Pimpinan akan dapat memonitor dan mengawasi para bawahan dalam batasan-batasan yang manusiawi. Dalam peran yang lebih luas, pimpinan dapat melakukan pendekatan dengan berbagai pihak baik secara konprehensif sehingga pimpinan dapat mengumpulkan lebih banyak informasi mengenai bawahan dan perusahaan yang dipimpinnya.

\section{Kajian Pustaka \\ Peranan}

Peranan berasal dari kata peran, diartikan sebagai pemain (Bahasa \& Nasional, 2005), "peran memiliki makna yaitu sejumlah komposisi tingkah dan tanggung jawab yang diharapkan dimiliki oleh orang yang berkedudukan di dalam masyarakat". Menurut (Thoha, 2001) "peranan adalah sebagai suatu rangkaian yang teratur, yang ditimbulkan karena suatu jabatan tertentu".

Peranan adalah bagian tugas utama yang harus dilakukan oleh seseorang yang memiliki tingkah dan tanggung jawab penting dalam sebuah komunitas, misalnya kepemimpinan seseorang dalam sebuah organisasi pada setiap pengambilan keputusan, sehingga dalam mengambil keputusan dan tanggung jawab terhadap hasilnya adalah hasil yang diharapkan oleh seorang pemimpin. Bila seorang pemimpin tidak mampu membuat keputusan, maka dia tidak dapat menjadi pemimpin. Dan bila sesorang pemimpin tidak tepat mengambil keputusan, maka sesuatu yang dipimpinnya tidak akan menghasilkan sesuatu yang diharapkan.

Berdasarkan beberapa pendapat di atas, maka peranan adalah bentuk pengaruh tingkah laku yang dilakukan oleh seseorang atau lebih dalam menghadapi suatu keadaan atau peristiwa yang ditimbulkan karena jabatan tertentu yang memberikan dampak kepada orang lain.

\section{Kepemimpinan}

Kepemimpinan atau leadership merupakan seni dan ketrampilan orang dalam memanfaatkan kekuasaan yang dimilikinya untuk mempengaruhi orang lain agar arah aktivitas yang dilakukan tercapat pada tujuan yang telah ditetapkan. Selain itu juga kepemimpinan merupakan sifat dari pemimpin dalam melaksanakan tugas dan kewajibannya serta tanggung jawabnya secara moral dan legal formal atas seluruh pelaksanaan wewenangnya yang telah didelegasikan kepada orang-orang yang dipimpinnya. kepemimpinan merupakan kemampuan seseorang untuk mempengaruhi, mengelola organisasi, mengawasi dan mengarahkan tingkah laku orang lain dalam mencapai tujuan bersama yang merancang untuk memberikan manfaat individu dan organisasi. Selain itu dapat pula dilihat bahwa kepemimpinan merupakan penentu atas keberhasilan dan kemunduran dari perusahaan yang dipimpinnya. Berhasil atau tidaknya seorang pemimpin dalam memimpin suatu organisasi sangat dipengaruhi oleh sejauh mana pemimpin itu memahami teori manajemen dan kepemimpinan dan bagaimana dia menerapkan gaya kepemimpinannya.

Literatur-literatur tentang kepemimpinan senantiasa memberikan penjelasan bagaimana menjadi pemimpin yang baik, sikap dan gaya yang sesuai dengan situasi kepemimpinan, dan syarat-syarat pemimpin yang baik. Berhasil atau gagalnya suatu organisasi ditentukan oleh kepemimpinan, 
karena pemimpinlah yang bertanggung jawab atas kegagalan pelaksanaan suatu pekerjaan, ini menunjukkan kedudukan posisi pemimpin di manapun letaknya akan selalu mempunyai beban untuk mempertanggungjawabkan kepemimpinannya.

Seorang pemimpin yang baik dalam menerapkan gaya tertentu dalam kepemimpinannya terlebih dahulu harus memahami siapa bawahan yang dipimpinnya, mengerti kekuatan dan kelemahan bawahannya, dan mengerti bagaimana cara memanfaatkan kekuatan bawahan untuk mengimbangi kelemahan yang mereka miliki.

\section{Tipe-tipe Kepemimpinan}

Saefullah (2012) mengatakan ada beberapa tipe-tipe kepemimpinan, yaitu:

\section{Tipe Pemimpin Otokratis}

Tipe pemimpin ini menganggap bahwa pemimpin adalah merupakan suatu hak. Adapun ciri ciri pemimpin tipe ini adalah:

a. Menganggap bahwa organisasi adalah milik pribadi.

b. Mengindentifikasikan tujuan pribadi dengan tujuan organisasi.

c. Menganggap bahwa bawahan adalah sebagai alat semata-mata.

d. Tidak mau menerima kritik, saran dan pendapat orang lain karena dia menganggap bahwa dialah yang paling benar.

e. Selalu bergantung dengan kekuasaan formal.

f. Dalam menggerakkan bawahan sering mempergunakan mendekatkan (Approach) yang mengandung unsur paksaan dan ancaman.

Dari sifat-sifat yang dimiliki tipe pemimpin otokratis tersebut di atas dapat diketahui bahwa tipe ini tidak menghargai hak-hak dari manusia, sehingga tipe ini tidak dapat dipakai dalam organisasi moderen.

\section{Tipe Pemimpin Militeristis}

Pemimpin yang bertipe militeristis ini mempunyai sifat-sifat sebagai berikut:

a. Dalam mengerakkan bawahan yang telah ditetapkan, perintah mencapai tujuan digunakan sebagai alat utama.

b. Dalam menggerakkan bawahan sangat suka menggunakan pangkat dan jabatannya.

c. Senang kepada formalitas yang berlebihan.

d. Menuntut disiplin yang tinggi dan kepatuhan mutlak dari bawahan.

e. Tidak mau menerima kritik dari bawahan.

f. Menggemari upacara-upacara untuk berbagai keadaan.

Dari sifat-sifat yang dimiliki oleh tipe pemimpin militeristis jelaslah bahwa tipe pemimpin seperti ini bukan merupakan pemimpin yang ideal.

\section{Tipe Pemimpin Paternalistis}

Tipe pemimpin paternalistis mempunyai ciri tertentu, yaitu bersifat paternal atau kebapakan. Kepemimpinan seperti ini menggunakan pengaruh yang sifat kebapakan dalam menggerakkan bawahan mencapai tujuan. Terkadang pendekatan yang dilakukan bersifat terlalu sentimental.

Tipe pemimpin ini mempunyai sifat-sifat sebagai berikut:

a. Menganggap bawahan sebagai manusia yang tidak dewasa.

b. Bersikap terlalu melindungi bawahan.

c. Jarang memberikan kesempatan kepada bawahannya untuk mengambil keputusan. Sehingga akan jarang dilakukan pelimpahan wawenang.

d. Jarang memberikan kesempatan kepada bawahannya untuk mengembangkan inisiatif daya kreasi karena tidak member kesempatan kepada bawahan untuk mengembangkan diri.

e. Sering menganggap dirinya serba tahu. 
Dilihat dari sifat-sifat tipe pemimpin ini, dalam keadaan tertentu pemimpin seperti ini sangat diperlukan.Akan tetapi, ditinjau dari segi sifat-sifat negatifnya pemimpin paternalistis kurang menunjukkan elemen kontinuitas terhadap organisasi yang dipimpinnya.

\section{Tipe Pemimpin Karismatik}

Tipe pemimpin seperti ini merupakan tipe pemimpin yang mempunyai daya tarik yang amat besar, sehingga mempunyai pengikut yang sangat besar.

Adapun ciri-ciri dari tipe pemimpin karismatik adalah sebagai berikut:

a. Memiliki kewibawaan alamiah.

b. Memiliki pengikut yang banyak.

c. Daya tarik metafisikal (terkadang irasional) terhadap para pengikutnya.

d. Terjadinya ketidaksadaran irasional dari tindakan pengikutnya.

e. Tidak dibentuk oleh faktor eksternal yang formal, seperti aturan legal formal, pelatihan atau pendidikan dan sebagainya.

f. Tidak dilatarbelakangi oleh faktor internal dirinya, misalnya fisik, ekonomi, kesehatan dan ketampanan.

\section{Tipe Pemimpin Demokratis}

Tipe pemimpin demokratis dianggap adalah tipe kepemimpinan yang terbaik. Hal ini disebabkan karena tipe kepemimpinan ini selalu mendahulukan kepentingan kelompok dari pada kepentingan individu.

Adapun ciri-ciri tipe pemimpin demokratis adalah sebagai berikut:

a. Dalam proses menggerakkan bawahan selalu bertitik tolak dari pendapat bahwa manusia adalah makhluk yang termulia di dunia.

b. Selalu berusaha menyelaraskan kepentingan dan tujuan pribadi dengan kepentingan organisasi.

c. Senang menerima saran, pendapat, bahkan dari kritik bawahannya.

d. Menolerir bawahan yang membuat kesalahan dengan tidak mengurangi daya kreativitas, inisiatif, dan prakarsa dari bawahan.

e. Lebih menitik beratkan kerja sama dalam mencapai tujuan.

f. Selalu berusaha untuk menjadikan bawahannya lebih sukses dari padanya.

g. Berusaha mengembangkan kapasitas diri pribadinya sebagai pemimpin dan lain-lain.

\section{Kinerja dan Faktor-Faktor yang Mempengaruhinya}

Menurut pendapat (Rivai \& Basri, 2005), "kinerja diartikan sebagai hasil atau tingkatan keberhasilan seseorang secara keseluruhan selama periode tertentu dalam melaksanakan tugas dibandingkan dengan standar hasil kerja, target atau sasaran atau kriteria yang telah ditentukan terlebih dahulu dan telah ditetapkan bersama".

Menurut (Tampubolon, 2007) faktor-faktor yang mempengaruhi kinerja adalah:

\section{Faktor Kemampuan}

Secara psikologis, kemampuan (Ability) seseorang terdiri dari kemampuan potensi (IQ) dan kemampuan reality (knowledge dan skill). Artinya seseorang yang memiliki IQ diatas rata-rata (IQ 110-120) apalagi IQ superior, very superior, gifted, dan genius dengan pendidikan yang memadai untuk menduduki jabatan tertentu dan terampil dalam mengerjakan pekerjaannya sehari-hari, maka ia akan lebih mudah mencapai kinerja yang maksimal. Oleh karena itu, seseorang tersebut perlu ditempatkan pada pekerjaan yang sesuai dengan keahliannya.

\section{Faktor Motivasi}


Motivasi terbentuk dari sikap seorang dalam menghadapi situasi kerja.Motivasi merupakan kondisi yang menggerakkan diri seseorang yang terarah untuk mencapai tujuan organisasi (tujuan kerja). Sikap mental merupakan kondisi mental yang mendorong diri seseorang untuk berusaha mencapai prestasi kerja secara maksimal. Sikap mental yang siap secara psikofisik, artinya seseorang harus siap mental, mampu secara fisik, memahami tujuan utama dan target kerja yang akan dicapai, mampu memanfaatkan dalam mencapai situasi kerja.

Menurut (Tampubolon, 2007) faktor-faktor kinerja terdiri dari:

\section{Faktor Internal}

Faktor yang dihubungkan dengan sifat-sifat seseorang, misalnya kinerja seseorang baik disebabkan karena mempunyai kemampuan tinggi dan seseorang itu memiliki tipe pekerja keras, apabila seseorang memiliki kinerja rendah disebabkan karena orang tersebut mempunyai kemampuan rendah serta tidak memiliki prakarsa atau usaha untuk memperbaiki kemampuan yang dimilikinya.

\section{Faktor Eksternal}

Faktor-faktor yang mempengaruhi kinerja seseorang yang berasal dari lingkungan. Seperti: perilaku, sikap, dan tindakan-tindakan rekan kerja, bawahan atau pimpinan, fasilitas kerja, dan iklim organisasi.

\section{Pegawai}

"Pegawai adalah orang yang bekerja pada pemerintah, perusahaan dan sebagainya dengan mendapatkan imbalan jasa berupa gaji atau upah dan tunjangan" (Bahasa \& Nasional, 2005). Dalam pasal 1 Sub a Undang-Undang No. 8 tahun 1974, tentang Undang-Undang pokok kepegawaian dikemukakan bahwa "pegawai adalah mereka yang memenuhi syarat-syarat yang ditentukan dalam peraturan perundang-undangan yang berlaku, diangkat oleh pejabat yang berwenang dan diserahi tugas negara lain dan ditetapkan berdasarkan sesuatu peraturan perundangundangan dan digaji menurut peraturan perundang-undangan yang berlaku".

Sehingga dapat dikatakan bahwa pegawai adalah seluruh individu yang diangkat oleh pejabat yang memiliki wewenang yang diserahi tugas dalam suatu jabatan negara atau tugas lainnya yang digaji berdasarkan peraturan dan perundang-undangan yang berlaku.

"Indikator untuk mengukur kinerja karyawan secara individu ada tiga indikator", yaitu (Nilamsari, 2018): (a) "Kuantitas yaitu jumlah yang harus diselesaikan atau dicapai, pengukuran kuantitatif melibatkan perhitungan keluaran dari proses atau pelaksanaan kegiatan”. Hal ini berkaitan dengan jumlah keluaran yang dihasilkan. (b) "Kualitas yaitu mutu yang harus dihasilkan, pengukuran kualitatif keluaran mencerminkan pengukuran tingkat kepuasan — seberapa baik penyelesaiannya". (c) "Ketepatan waktu yaitu sesuai tidaknya dengan waktu yang direncanakan"

\section{Metode Penelitian}

Dalam penelitian ini pendekatan yang digunakan adalah melalui pendekatan kualitatif. Artinya data yang dikumpulkan bukan berupa angka-angka, melainkan data tersebut berasal dari naskah wawancara, kajian lapangan, dokumen pribadi, catatan, memo dan dokumen resmi lainnya. Sehingga yang menjadi tujuan dari penelitian kualitatif ini adalah ingin mengambarkan realita empirik di balik fenomena secara mendalam, rincian dan tuntas. Oleh karena itu penggunaan pendekatan kualitatif dalam penelitian ini adalah dengan mencocokkan antara realita empirik dengan teori yang berlaku dengan menggunakan metode deskriptif (Lexy:2004).

\section{Hasil}

\section{Sejarah Singkat Biro Tata Pemerintahan Sekretariat Daerah Aceh}


Biro Tata Pemerintahan adalah salah satu subunit kerja di lingkungan Sekretariat Daerah Provinsi Aceh yang merupakan unsur pembantu Asisten Pemerintahan di bidang penyelenggaraan Pemerintahan. Beralamat Kantor Gubernur di Jl. T. Nyak Arif No. 219 Banda Aceh. Paralel kedudukannya Biro Tata Pemerintahan mempunyai tugas pokok dan fungsi dalam melaksanakan tugasnya, Biro Tata Pemerintahan Sekretariat Daerah Aceh berlandaskan pada tujuan, Sasaran, dan Program kerja yang ditetapkan baik dalam Rencana Pembangunan Jangka Menengah Aceh (RPJMA), Rencana Kerja Aceh (RKA), dan Rencana Strategis (RENSTRA).

Pemerintah Aceh merupakan daerah otonomi khusus dalam ikatan Negara Kesatuan Republik Indonesia. UU No. 11 Tahun 2006 mempertegas kewenangan daerah untuk mengurus dan mengatur kepentingan masyarakat lokal menurut prakarsa sendiri dengan berlandaskan pada aspirasi masyarakat sesuai dengan peraturan perundang-undangan yang berlaku yang berlandaskan pasa azas penyelenggaraan pemerintah daerah yang terdiri azas desentralisasi, dekonsentralisasi, dan tugas pembantu.

Pemerintahan daerah memiliki kewenangan yang luas, nyata dan bertanggung jawab. Dalam rangka menindaklanjuti kewenangan-kewenangan yang diberikan serta sesuai dengan potensi dan aspirasi daerah, pemerintah Aceh telah melakukan penataan-penataan, baik menyangkut kelembagaan maupun personalianya. Sekretariat Daerah terdiri Asisten, Biro dan Bagian-bagian serta Sub-sub Bagian, Dinas Daerah dan Lembaga Teknis Daerah yang berbentuk Badan dan Kantor.

\section{Tugas Pokok dan Fungsi Biro Tata Pemerintahan Sekretariat Daerah Provinsi Aceh}

1. Tugas Pokok

Menyiapkan bahan pembinaan, evaluasi penyelenggaraan pemerintahan umum, pengembangan perangkat daerah serta pembinaan otonomi daerah, keamanan dan ketertiban serta pembinaan perangkat pemerintahan mukim dan gampong serta kependudukan dan urusan pemerintahan yang bersifat tampung tentra.

2. Fungsi

a. Penyiapan bahan pembinaan kegiatan dan administrasi bagi perangkat pemerintahan daerah.

b. Penyiapan bahan pembinaan penyelenggaraan koordinasi Pemerintahan umum, serta penyusunan rencana program dan petunjuk teknis pembinaan prasarana fisik Pemerintahan dan pertanahan.

c. Penyiapan bahan pembinaan keuangan mukim dan gampong.

d. Penyiapan bahan pembinaan dan pengembangan perangkat Pemerintahan mukim dan gampong.

e. Penyiapan bahan pembinaan administrasi kependudukan dan catatan sipil.

f. Penyiapan bahan pembinaan dan petunjuk teknis pelaksanaan otonomi daerah dan otonomi khusus, tugas pembantu dan evaluasi, penyelenggaraan Pemerintahan umum dan otonomi daerah dan otonomi khusus.

g. Penyiapan bahan pembinaan dan petunjuk teknis penyelenggaraan Pemerintahan Kota.

h. Penyiapan bahan pembinaan dan petunjuk teknis pelaksanaan keamanan, ketertiban dan ketenagakerjaan.

i. Pelaksanaan tugas-tugas kedinasan lainnya yang diberikan oleh SEKDA melalui Asisten Pemerintahan.

\section{Peranan Kepemimpinan dalam Meningkatkan Etos Kinerja Pegawai pada Biro Tata Pemerintahan Sekretariat Daerah Provinsi Aceh}

Biro Tata Pemerintahan adalah salah satu sub unit kerja di lingkungan Sekretariat Daerah Provinsi Aceh, dipimpin oleh seorang Kepala Biro yang merupakan unsur pembantu Asisten Pemerintahan di bidang penyelenggaraan pemerintahan. Biro Tata Pemerintahan mempunyai tugas menyiapkan 
bahan pembinaan, pengembangan perangkat daerah, evaluasi penyelenggaraan pemerintahan umum, serta pembinaan otonomi daerah, keamanan dan ketertiban serta pembinaan perangkat pemerintahan mukim dan gampong serta kependudukan dan urusan pemerintahan yang bersifat tampung tentra.

Dengan tugas tersebut Kepala Biro Tata Pemerintahan juga menyelenggarakan fungsi. Untuk melaksanakan tugas dan fungsi tersebut maka Biro Tata Pemerintahan pada Sekretariat Daerah Provinsi Aceh mempekerjakan 62 orang pegawai yang berada kepemimpinan kepala Biro. Dengan menjadi pemimpin, Kepala Biro mendapatkan kedudukan yang tinggi dalam lingkungannya beserta kekuasaan, fasilitas hidup, bantuan dan serta tunjangan yang melekat pada jabatannya. Namun inti kepemimpinan semata-mata bukan terletak pada jabatan, namun merupakan tugas dan fungsi. Kepala Biro dengan segenap sumber daya yang ada hadir untuk mencapai tugas-tugas pemerintah Provinsi Aceh. Kepala Biro diangkat untuk menyelesaikan berbagai muatan masalah yang menghadang Satuan Kerja Perangkat daerah dalam pelaksanaan tugas Pemerintah Provinsi Aceh.

Dalam proses kepemimpinannya Kepala Biro berhadapan dengan berbagai bentuk perilaku pegawai yang relatif unik dan berbeda. Dari sejumlah perilaku yang ada, kinerja pegawai menjadi masalah yang tidak mudah dikendalikan dan mempengaruhi Biro Tata Pemerintahan dalam pencapaian program kerja pemerintah. Sehingga jika dilihat lebih dekat ada sebagian pegawai pada Biro Tata Pemerintahan Sekretariat Daerah Provinsi Aceh yang bekerja dengan giat, ada pegawai yang bekerja dengan waktu yang sedikit itupun jika adanya tugas-tugas mendesak yang diperintahkan oleh atasan dan bahkan ada sebahagian pegawai hanya datang ke kantor dan banyak menghabiskan waktu luangnya di tempat kerja tanpa adanya pekerjaan yang berarti. Di tengah tidak menentunya kinerja pegawai, maka sadar atau tidak Kepala Biro telah melaksanakan berbagai bentuk peran kepemimpinannya untuk meningkatkan kinerja yaitu sebagai berikut:

\section{Pembagian Tugas}

Pembagian kerja adalah kegiatan Kepala Biro untuk mengalokasikan tugas-tugas sesuai dengan bidang, catatan pendidikan dan keahlian masing-masing. Dengan adanya pembagian kerja yang efektif akan membuat beban kerja dapat terdistribusi secara merata dan tidak membuat pegawai kelebihan dan kekuarangan beban kerja. Dengan pembagian kerja yang efektif pegawai juga dapat melaksanakan tugas sesuai dengan keahlian dan pendidikannya. Justru tanpa adanya pembagian kerja yang efektif, pegawai Biro Pemerintahan pada Sekretariat Daerah Aceh akan bekerja menurut kemauan sendiri-sendiri tanpa menghiraukan tujuan instansi. Beberapa yang melatar belakangi Kepala Biro Pemerintahan pada Sekretariat Daerah Provinsi Aceh dalam melakukan pembagian kerja adalah:
a. Setiap pegawai mempunyai kemampuan, kecakapan dan spesialisasi kerja yang berbeda.
b. Setiap pegawai tidak dapat berada dalam waktu yang sama.
c. Setiap pegawai tidak dapat mengerjakan dua hal pada saat yang bersamaan.
d. Begitu luasnya bidang pengetahuan yang mungkin dikuasai oleh satu orang pegawai.

Dalam pembagian kerja, Kepala Biro selalu menyesuaikan antara kemampuan dan jenis pekerjaan yang akan ditangani, di samping itu disertai oleh prosedur dan target waktu yang mudah dilalui oleh pegawai. Dengan adanya pembagian kerja yang efektif, maka akan dapat diperoleh beberapa manfaat antara lain:

a. Pegawai Biro Pemerintahan pada Sekretariat Daerah Provinsi Aceh dapat melaksanakan tugas pekerjaannya tanpa menunggu perintah atau komando.

b. Pegawai Biro Pemerintahan pada Sekretariat Daerah Provinsi Aceh dapat mengetahui dengan jelas wewenang dan tanggung jawab dari pekerjaan itu. 
c. Pegawai Biro Pemerintahan pada Sekretariat Daerah Provinsi Aceh tidak meragukan dalam pelaksanaan pekerjaan.

d. Kepala Biro dapat dengan mudah dalam melakukan pengawasan

e. Tidak terjadinya tumpang tindih atau benturan tugas pada Biro Pemerintahan pada Sekretariat Daerah Provinsi Aceh.

\section{Menjelaskan Sasaran Tugas}

Kepala Biro Pemerintahan pada Sekretariat Daerah Provinsi Aceh selaku pemberi tugas kepada bawahannya yaitu sejumlah kepala Bagian, akan selalu menjelaskan arah penyelesaian tugas-tugas yang diberikan kepada bawahan. Kejelasan sasaran tugas merupakan sejauh mana tugas-tugas yang dilaksanakan pegawai pada Biro Pemerintahan pada Sekretariat Daerah Provinsi Aceh dapat diketahui manfaat dan tujuan akhir dari pelaksanaan tugas tersebut. Kegiatan ini membuat pegawai mengerti dan memahami tugas-tugas yang dikerjakannya meliputi batas waktu yang diharapkan untuk penyelesaian tugas tersebut. Adapun kegiatan yang dilakukan Kepala Biro Pemerintahan dalam menjelaskan sasaran tugas adalah sebagai berikut:

a. Menjelaskan tujuan akhir dari tugas yang dikerjakan

b. Menjelaskan hasil dan manfaat yang ingin dicapai

c. Menjelaskan standar-standar pekerjaan yang harus dipenuhi

d. Menjelaskan jangka waktu kebutuhan tugas yang harus diselesaikan

e. Menjelaskan sasaran prioritas tugas yang diutamakan

f. Menjelaskan tingkat kesulitan yang akan dihadapi.

Penetapan tujuan tugas yang lebih jelas dan spesifik bagi pegawai akan dapat memotivasi pegawai untuk melakukan hal yang terbaik sesuai dengan kemampuan mereka. Justru tanpa adanya kejelasan tugas akan membuat mereka banyak menemukan hambatan, kebingungan, ketegangan dan ketidakpuasan dalam bekerja. Dengan adanya kejelasan tugas akan mendorong para pegawai untuk melakukan yang terbaik dalam kerja mereka, dan mereka akan lebih mampu mengatur perilaku dan waktu yang akhirnya dapat meningkatkan kinerja mereka sendiri.

\section{Mendelegasikan Tugas}

Kegiatan pendelegasian wewenang merupakan suatu proses meneruskan suatu tanggung jawab oleh Kepala Biro, di mana sebahagian fungsi pekerjaan yang tadinya dilaksanakan sendiri oleh Kepala Biro, kini sebahagian dilimpahkan kepada bawahan. Dengan meneruskan suatu tugas-tugas berarti membuat para bawahan juga ikut bertanggung jawab terhadap hasil yang akan dicapai dari tugas tersebut.

Semakin luas dan berkembangnya keorganisasian Pemerintah Provinsi Provinsi Aceh, membuat semakin bertambahnya tugas-tugas kepala Biro yang tidak terduga dan sebahagian dari tugas tersebut dapat dilimpahkan kepada bawahan. Kondisi ini membuat Kepala Biro Pemerintahan pada Sekretariat Daerah Provinsi Aceh ikut mendelegasikan sejumlah tuigas-tugasnya kepada bawahan. Dengan adanya delegasi tugas, pegawai yang memiliki waktu sedikit akan dapat dimanfaatkan oleh Kepala Biro sehingga pegawai dapat bekerja secara optimal.

\section{Pemanfaatan Sumber Daya Instansi}

Meningkatnya program kerja pemerintah dan pembangunan di Provinsi Aceh akan berkorelasi dengan meningkatnya tugas-tugas pegawai pada Biro Pemerintahan pada Sekretariat Daerah Provinsi Aceh. Agar aktivitas pegawai dalam pelaksanaan program kerja Biro Pemerintahan pada Sekretariat Daerah Aceh tidak terganggu, maka Kepala Biro berperan untuk mengalokasikan anggaran belanja untuk berbagai kebutuhan pengadaan fasilitas kerja, pengembangan sarana dan prasarana kerja serta dan bahkaan penambahan pegawai kontrak. Dengan kegiatan tersebut Kepala 
Biro telah dapat mengatasi gangguan-gangguan yang menghambat aktivitas kerja pegawai. Untuk mengusulkan dan memperoleh anggaran belanja maka Kepala Biro melakukan langkah-langlkah sebagai berikut:

a. Mengadakan rapat koordinasi dengan kepala bidang dan sub bagian untuk mengetahui perkiraan kebutuhan anggaran

b. Mengajukan perencanaan anggaran pada Biro Keuangan dan Penyusunan program Kantor Sekretariat Daerah Aceh

c. Melakukan pertemuan-pertemuan dengan Biro Keuangan dan Penyusunan Program maupun pihak lainnya sebagai langkah pengawalan anggaran

d. Menggunakan anggaran yang telah disetujui sesuai dengan rencana-rencana kebutuhannya.

Selain berusahan menyediakan dan mengelola sumber dana untuk memajukan dan mengembangkan sarana dan prasarana, Kepala Biro juga dapat memperbaharuhi dan memenuhi fasilitas kerja dengan anggaran yang ada. Lebih dari itu Kepala Biro dapat memanfaatkan seluruh sumber daya organisasi sehinggan apa yang dibutuhkan pegawai dapat terakomodasi.

\section{Mengumpulkan dan Menyebarkan Informasi}

Untuk mengetahui segala aktivitas dan kondisi yang terjadi dalam lingkungan kerja Biro Tata Pemerintahan, Kepala Biro terus menerus memonitor setiap tindakan yang dikerjakan oleh bawahannya melalui berbagai nara sumber terpercaya. Dengan kegiatan monitoring, pimpinan akan memperoleh berbagai bentuk informasi internal untuk pengambilan keputusan. Dengan kegiatan tersebut Kepala Biro disamping dapat mengetahui kebutuhan-kebutuhan yang diinginkan pegawai, juga dapat mengetahui keluhan-keluhan yang disampaikan oleh para bawahan. Dengan informasi yang didapat tersebut Kepala Biro dapat melakukan perbaikan dan memenuhi tuntutan yang ada.

Selain mengumpulkan informasi, Kepala Biro juga dengan cepat dan uptodate dapat menyebarkan informasi-informasi eksternal yang positif dan dibutuhkan oleh pegawai. Perkembangan lingkungan eksternal yang sangat dinamis perkembangannya akan dapat ditelaah dan diidentifikasi oleh Kepala Biro dari berbagai media terpercaya. Kondisi ini membuat Kepala Biro memiliki data dan informasi untuk disebarluaskan kepada bawahan. Dengan mengetahui berbagai informasi terutama yang berkaitan dengan tugas dan karirnya, membuat pegawai memiliki kesiapan untuk menyesuaikan diri dengan berbagai bentuk perkembangan dan perubahan. Kondisi ini akan berdampak terhadap kinerja pegawai.

\section{Menyelesaikan Konflik}

Diangkatnya seseorang Kepala Biro Tata Pemerintahan pada Kantor Sekretariat Daerah dilatar belakangi untuk dapat bertindak dan mengatur setiap masalah yang dihadapi Pegawai. Kepala Biro akan bertanggung jawab kepada Sekretariat setiap tindakan yang dikerjakan oleh Pegawai di lingkungan kerjanya. Dengan demikian menjadi tugas Kepala Biro untuk menciptakan sistem kerja dan hubungan kerja yang baik dengan berbagai pihak, khususnya antara pegawai dengan pegawai. Setiap pegawai pada Biro Tata Pemerintahan pada Kantor Sekretariat Daerah memiliki potensi untuk mengalami berkonflik di mana saja dan kapan saja. Hal tersebut disebabkan oleh keberagaman yang ada dalam diri pegawai seperti karakter, nilai - nilai pribadi, agama, sosial dan budaya. Selain konflik atar personal, pegawai juga mengalami konflik dalam bekerja atau yang biasaa dikenaal dengan konflik peran. Konflik peran terjadi akibat ketidakcocokan tugas atau pegawai menghadapi ketidakkonsistenan antara tugas yang diterima tidak sebanding atau sesuai dengan perilaku perannya. Konflik pada pegawai juga dapat terjadi ketika peran dengan beban kerja dan rumusan tanggungjawab yang berlebihan. Konflik telah membuat pegawai tidak 
menemukan kepuasan dalam bekerja dan berakibat pada pelaksanaan pekerjaan yang tidak pernah efektif dan tidak efesien. Untuk itu Kepala Biro selalu penyelesaian konflik dengan cara.

a. Mengadakan pertemuan dan rapat tertutup

Salah satu peran Kepala Biro, dimana melakukan tukar menukar informasi mengenai konflik yang terjadi. Di sini Kepala biro dapat mengetahui perbedaan dan mencari silusi yang dapat diterima oleh semua pegawai. Kegiatan ini jarang dilakukan dan jika adanya konflik yang konfleks pada Biro.

b. Menyelesaikan konflik dengan kerelaan membantu

Kepala Biro rela membantu seorang atau sekelompok pegawai yang mengalami konflik dengan cara dengan memberikan beberapa bentuk fasilitas dan kompensasi kerja kepada seorang atau sekelompok pegawai yang mengalami konflik. Dengan kegiatan ini Kepala Biro mengangkat atau menghargai seseorang atau sekelompok orang dibanding yang lainnya, sehingga kegiatan ini akan membuat beban pegawai merasa lebih ringan dan tenang dalam bekerja.

c. Menyelesaikan konflik dengan kompromi

Kepala Biro menyelesaikan konflik dengan pertemuan pihak-pihak yang menghadapi konflik dan kemudian mengambil jalan tengah. Kegiatan ini sangat dominan dilakukan terutama untuk masalah-msalah kecil yang menghambat aktivitas pegawai.

\section{Melakukan Supervisi dan Pengawasan}

Pengawasan merupakan kegiatan Kepala Biro dalam melakukan pemeriksaan pekerjaan, penilaian pekerjaan, evaluasi dan melakukan pemantauan baik secara langusung maupun tidak langsung atas setiap aktivitas kerja pegawai sehingga dapat diketahui apa yang harus dicapai oleh pegawai, apa yang sedang dilakukan oleh pegawai dan sejauh mana telah dilaksanakan serta bila perlu dilakukan perbaikan perbaikan atas setiap kendala. Dengan adanya pengawasan maka Kepala Biro dapat menjamin terlaksananya aktivitas kerja pegawai sesuai prosedur dan standar.

\section{Simpulan}

Biro Tata Pemerintahan pada Sekretariat Daerah Provinsi Aceh mempekerjakan 62 orang pegawai yang berada kepemimpinan kepala Biro. Namun jumlah komposisi pegawai yang lebih besar dari beban kerja membuat kinerja pegawai pada Biro ini perlu diperhatikan. Masih terdapat sejumlah pegawai yang tidak mendapatkan pekerjaan dengan jelas sehingga membuka peluang bagi mereka untuk menggunakan waktu dengan kegiatan-kegiatan yang tidak bermanfaat. Kemudian kebijakan penempatan dan pembagian kerja yang tidak dilakukan secara propesional juga membuat kinerja pegawai pada Biro ini masih perlu diperhatikan. Di tengah semakin cepatnya perubahan lingkungan kerja yang ikut mempengaruhi perilaku kerja pegawai, maka Pemerintahan pada Sekretariat Daerah Provinsi Aceh membutuhkan pimpinan yang berkualitas agar masalah-masalah yang berkaitan dengan perilaku kerja dan kinerja pegawai dapat terselesaikan. Sehingga peranan kepemimpinan sangat penting dalam meningkatkan kinerja pegawai.

\section{Daftar Pustaka}

Bahasa, P., \& Nasional, D. P. (2007). Kamus Besar Bahasa Indonesia : Edisi Ketiga. Jakarta: Balai Pustaka.

Lexy J Moleong. (2004). Metode Penelitian Kualitatif. Bandung: Remaja Rosda Karya Nilamsari, D. P. (2018). Pengukuran Kinerja Tenaga Profesional Pada Organisasi Jasa (Studi Kasus Kotabahasa Salatiga). JEMAP, 129-145.

Rivai, V., \& Basri, A. F. (2005). Performance Appraisal Sistem Yang Tepat Untuk Menilai Kinerja Karyawan Dan Meningkatkan Daya Saing Perusahaan. Jakarta: PT. Raja Grafindo Persada.

Saefullah, U. (2012). Manajemen Pendidikan Islam. Jakarta: Pustaka Setia. 


\section{eCo-Buss}

Tampubolon, B. D. (2007). Analisis Faktor Gaya Kepemimpinan Dan Faktor Etos Kerja Terhadap Kinerja Pegawai Pada Organisasi Yang Telah Menerapkan Sni 19-9001-2001. Jurnal Standarisasi, 106-115.

Taneko, S. B. (1986). Konsepsi Sistem Sosial dan Sistem Sosial Indonesia. Jakarta: Fajar Agung. Thoha, M. (2001). Perilaku Organisasi : Konsep Dasar dan Aplikasinya. Jakarta: CV. Rajawali. Thoha, M. (2007). Kepemimpinan dalam Manajemen. Edisi 12. Jakarta: PT. Raja Grafindo Persada. 